\title{
INNOVATIVE USE OF MAGNESIUM OXIDE IN THE TREATMENT OF "NEURALGIA OF THE CELIAC PLEXUS OF RHEUMATIC ORIGIN" BY G. MOSCATI IN 1923
}

\author{
INOVATIVNA UPORABA MAGNEZIJEVA \\ OKSIDA U LIJEČENJU "NEURALGIJE \\ CELIJAČNOG PLEKSUSA REUMATOIDNOG \\ PODRIJETLA" G. MOSCATIJA 1923.
}

\author{
Michele Colaci", Giovanni Ponti**
}

\begin{abstract}
SUMMARY
We presented and discussed one interesting medical prescription by doctor Giuseppe Moscati (I880-1927), who prescribed magnesium oxide (magnesia usta) to a patient with the diagnosis of "neuralgia of the celiac plexus of rheumatic origin". Besides the traditional use of magnesium as antacid remedy at the time, we raised the hypothesis that magnesium could be administered by Moscati in order to treat the neuralgia itself. Considering the scientific background of Moscati at the school of Filippo Bottazzi (I867-I94I), a father of Italian biochemistry, we suggested that the doctor tried to apply the preliminary concepts acquired from electrophysiological studies on magnesium to his clinical practice. Only after decades, magnesium was recognized a fundamental ion in the energy metabolism and in contributing to maintain the ionic intracellular homeostasis, including for neurons.
\end{abstract}

Keywords: Giuseppe Moscati, Filippo Bottazzi, Magnesium oxide, magnesia usta, neuralgia, celiac plexus

Rheumatology Unit, University of Modena and Reggio Emilia, Italy.

*** Clinical Pathology Unit, University of Modena and Reggio Emilia, Modena, Italy.

Correspondence address: Giovanni Ponti, Department of Diagnostic and Clinical

Medicine and Public Health, University of Modena and Reggio Emilia, Via del Pozzo n 71, 41124 Modena, Italy. E-mail: giovanni.ponti@unimore.it. 


\section{INTRODUCTION}

Magnesium plays a critical role in a number of physiological processes, including the modulation of nociception by means of the antagonistic action on the N-methyl-d-aspartate (NMDA) receptors (I, 2). Indeed, this scientific acquisition resulted from researches carried on in the last decade of the $20^{\text {th }}$ century (3). Nowadays, magnesium sulphate is considered a useful adjuvant in obstetric anaesthesia and intensive care thanks to its favourable effect in reducing analgesic therapy or prolonging the duration of anaesthesia (4); nonetheless, in any case magnesium is considered useful in the treatment of chronic painful disorders, such as migraine (5) and fibromyalgia (6).

In the present article, we aimed to discuss one interesting document by Giuseppe Moscati (1880-1927), who prescribed magnesium to a patient affected by celiac plexus nerve pain (Fig I). Giuseppe Moscati was an eminent physician of the first part of the 2oth century, medical doctor and professor at the University of Naples (7-9).
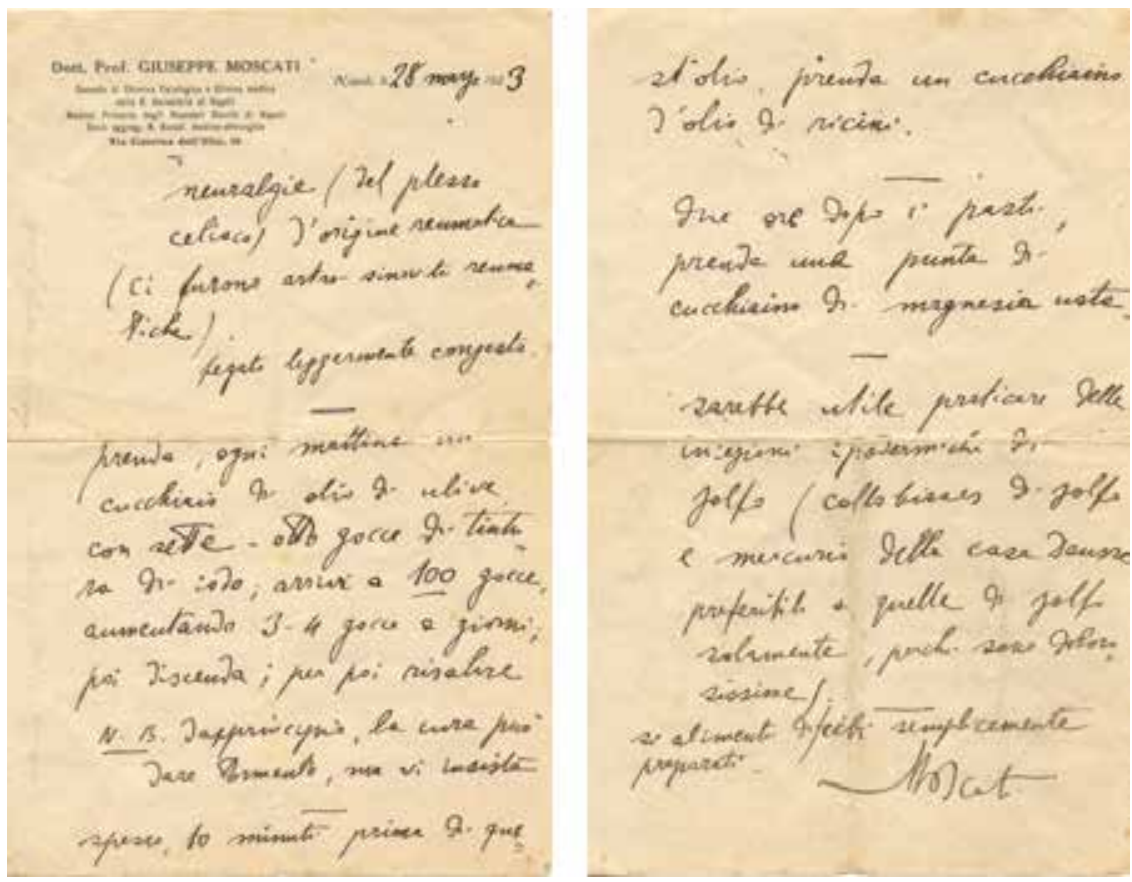

Fig. I. Giuseppe Moscati's prescription for a patient with "neuralgia (del plesso celiaco) d'origine reumatica (ci furono artro-sinoviti reumatiche); fegato leggermente congesto", that is "neuralgia (of the celiac plexus) of rheumatic origin (there were rheumatic arthro-synovites); mild liver congestion".

Dated 28 March 1923. 
Moscati's prescription of magnesium for a patient with chronic pain is very intriguing, because it points to the concept that ions play a role in the pathogenesis of neural disorders. In this light, magnesium might be prescribed in order to modulate the pain, besides its traditional use an antacid. To the best of our knowledge, no other coeval documents show the magnesium oxide prescription for pain management. During the first decades of the $20^{\text {th }}$ century, it was recognized that many pathological conditions were correlated to $\mathrm{Mg}$ deficiency. However, since the uptake and the release of $\mathrm{Mg}$ depend on many factors, the mechanisms of its intracellular homeostasis were almost unknown. In the following years, it was ascertained that $\mathrm{Mg}$ has a critical role in the energy metabolism and in maintaining the ionic intracellular homeostasis in association with potassium and calcium by a mechanisms of intake or release requiring energy (ATP). The molecular mechanisms of these functions were investigated and progressively resolved in the second half of the $20^{\text {th }}$ century. Keynes, working with the great neurophysiologist Hodgkin AL, carried out experiments with radioactive tracers to follow movements of ions (IO). In 1957, Skou demonstrated that the transport of sodium and potassium in-and-out the intracellular milieu through the cellular plasma membrane requires energy supplied by a membrane ATPase (II). The mechanism of $\mathrm{Mg}$ in muscle contraction/relaxation cycle was revealed in rg6r by the experiments on isolated sarcoplasmic reticulum fragments carried out by Muscatello (I2-I4) and the critical role of calcium pump by sarcoplasmic reticulum was shown by Weber AM in the same years ( 15,16$)$.

\section{MOSCATI'S PRESCRIPTION}

We present Moscati's medical prescription (Fig. I), housed in the museum dedicated to doctor, next to the Chiesa del Gesù Nuovo in Naples. The museum keeps more than 300 Moscati's medical documents, which have also been digitally recorded.

The present document, dated 28 March I923, shows an unknown patient's diagnosis of 'neuralgia of the celiac plexus of rheumatic origin'. Any other information regarding this patient, such as age or gender, is unavailable. The prescribed therapy consists of a few remedies, well separated by a horizontal stretch of the pen: $\mathrm{r}$. iodine tincture diluted in olive oil, with an increasing-decreasing dosages schedule, preceded by a small amount of castor oil; 2. magnesia usta (magnesium oxide, $\mathrm{MgO}$ ); 3. sulphur hypodermic injections (preferably a colloidal sulphur drug produced by the Dausse manufacturer). 
Moscati's prescription seems to follow a logical pattern starting from the patient's symptoms and ending in the hypothesized etiology of the disease.

The first remedy would suggest the resetting of the gastrointestinal function with a known irritating drug, able to induce hyperthyroidism, classi-

cally administered orally for tubercular lymphadenitis ('scrofula'), goitre, secondary form of syphilis, but also for nervous non-inflammatory diseases, particularly gastric neuralgias (I7). The iodine therapy was preceded by a teaspoon of castor oil, as an associated remedy, probably in order to accelerate the intestinal transit of the primary drug that was known to be toxic; the Ioo drops contained up to $300 \mathrm{mg}$ of iodine (I8). Moreover, Moscati's awareness of this toxicity is evidenced by the increasing-decreasing schedule of administration and because it was explicitly indicated to the patient with the 'N.B.' (Latin abbreviation for 'nota bene', note well) comment.

The second treatment consists of a very small amount (a teaspoon tip) of $\mathrm{MgO}$, taken 2 hours after meals. The traditional use of a small quantity of this medical powder was as an antacid treatment, and its administration timing may support this rational of use. Moreover, this lenitive purpose may be suggested by the previous administration of an irritating drug. However, a second interpretation could be suggested: $\mathrm{MgO}$ could have been prescribed to directly counteract the neuralgia, as a 'pathogenetic' treatment.

Lastly, the third prescription points to treat the presumed cause of the neuralgia, which is 'rheumatism'. This 'etiologic' therapy consists in parenteral administration of sulphur, according to the knowledge of the time (I9, 20). To note, Moscati indicated to the patient that sulphur injections were very painful, so the colloidal product by Dausse was preferable.

\section{Discussion}

Moscati's prescription shows a diagnosis of neuralgia of the celiac plexus of rheumatic origin. No patient's information is given, with the exception of a mild liver congestion. We may presume that it was the case of an adult subject on the basis of the high dose of iodine tincture prescribed. The diagnosis of neuralgia was not a novelty, since the anatomy and the physiology of the celiac plexus were well known, as well as the possibility of painful syndromes of the abdominal organs innervated by the plexus (2I). With the term 'celiac neuralgia' a disorder was diagnosed characterized by spontaneous paroxysmal recurrent pain in the epigastric region, without dyspepsia and other digestive disturbances; the pain is sudden and may disappear after 
a few minutes, and the pressure at the epigastrium alleviates the symptom; finally, the pain is associated with a feeling of extreme faintness and anxiety, as well as in angina pectoris (22). Indeed, this non-organic disorder was attributed to the young-middle aged people, much more frequently in women, frequently connected with hysteria; the actual etiology was unknown (22). Given the very scarce diagnostic possibility of the time, the 'celiac neuralgia' could be attributed to several diseases; however, the exclusion of an organic etiology and the association with the anxious disorders assists in the hypothesis of a psychosomatic disease, i.e. fibromyalgia. Moreover, neuralgias were recognized as a consequence of several endogenous intoxications, i.e. of rheumatic origin (23). The treatment of neuralgia included several symptomatic remedies, such as arnica, calendula, artemisia, valeriana, opium, belladonna, nux vomica, strychnia, sugar, carbon, bismuth, arsenic, citrate of iron, and iodine (22); the latter was indicated for chronic neuralgia, in addition to analgesics (23).

All the remedies from the Moscati's prescription discussed in this article were well known and used by doctors in the same period; indeed, these treatments may be easily considered within the clinical use of the time, on the basis of the concepts obtained from the contemporary literature (17-20, 23). However, with regards to $\mathrm{MgO}$, an interesting hypothesis regarding the rational of use could be raised. The prescription of magnesium salts by Moscati was frequently found in the corpus of more than 300 medical prescriptions preserved in the museum of the Chiesa del Gesù Nuovo, Naples. However, while the magnesium citrate was often prescribed for purgative purpose (generally explicitly indicated by Moscati), only 2 documents, including the present, reported 'magnesia usta' for 2 patients affected by painful epigastric disorders.

The Italian term "magnesia usta" indicated a galenic preparation of $\mathrm{MgO}$, obtained from magnesium carbonate kept in a red heat for 2 hours (calcination). $\mathrm{MgO}$, which looks like bulky white powder, was used as a purgative treatment from as early as the $18^{\text {th }}$ century (24). Moreover, $\mathrm{MgO}$ was considered a valid treatment for dyspepsia and acidity, and it was preferable to magnesium carbonate, because the neutralization of the acid of the stomach was obtained without any production of gas $(25,26)$. Differently, the other authors attributed to $\mathrm{MgO}$ the ability to reduce the intestinal irritability in patients with diarrhoea (27). Again, $\mathrm{MgO}$ was indicated as a valuable remedy against some poisons (such as phosphorus, arsenic or acids) or the production of renal uric acid deposits ( 17 ); indeed, the name "magnesium" itself 
derives from the Latin "magnes" (magnet), stressing the property of Mg salts to attract the 'bad humors' in the body, as supposed universal medical remedy. In order to achieve the antacid effect whilst avoiding the laxative properties, the physician could moderate the dose of dispensed $\mathrm{MgO}$, preventing further discomfort for the patients (17).

Besides the traditional use of 'magnesia usta', Moscati might have prescribed $\mathrm{MgO}$ to treat the neuralgic pain. In other words, it was possible that the professor used $\mathrm{MgO}$ as a specific remedy against neuralgia. This hypothesis can be verified by means of the evaluation of the other Moscati's documents. In fact, differently from several other prescriptions of magnesium citrate (sometimes named 'magnesia purgativa') which was prescribed in order to achieve a faster intestinal transit, $\mathrm{MgO}$ was used in only 2 cases of epigastralgia, namely our case of "celiac neuralgia" and another case of painful "gastric erosion". Therefore, the prescription of $\mathrm{MgO}$ could be explained with the aim to alleviate patient's gastric discomfort. Secondly, $\mathrm{MgO}$, prescribed 2 hours after meals, was traditionally used as an antacid treatment. However, the diagnosis of celiac neuralgia indicated a non-organic disorder of the stomach, which did not require antacids. Moreover, in the other case of "gastric erosion", the prescription of $\mathrm{MgO}$ was associated with bismuth carbonate, which was largely employed as remedy for dyspepsia in the $20^{\text {th }}$ century (28). Thus, it was possible that Moscati used $\mathrm{MgO}$ to treat the pain itself, which was primitive, neuropathic in the first case and consequent to gastric erosion in the second one. This hypothesis is also supported by the lack of prescription of typical analgesic drugs that were widely used at the time (22).

In the first decades of the $20^{\text {th }}$ century, there was no medical knowledge which indicated the use of $\mathrm{MgO}$ as a therapy against celiac neuralgia, therefore Moscati used magnesia usta in this neuropathic disorder probably on the basis of personal observations. Interestingly, the effect of the magnesium in the physiologic electrical processes of the muscular cells was studied by several European physiologists at the Moscati's time, including also the Bottazzi's school, which Moscati belonged to (29). In fact, several researchers described the curare-like effect of magnesium on muscle tissue (30). Moreover, previous observations had suggested the use of $\mathrm{MgO}$ as an antispastic therapy (27). Therefore, it was plausible that Moscati applied to his clinical practice the new knowledge coming from the novel scientific discipline named "physic chemistry" (biochemistry), consistently with the current concepts of translational medicine. 
Nowadays, the therapeutic role of magnesium has considerably expanded, thanks to the discovery of its importance in the electrophysiological processes of the muscular and neuronal cells (3I, 32). Indeed, Mg cations regulate, via the $\mathrm{Ca} / \mathrm{Mg}$ ratio, the release of all the neurotransmitters, the opening of NMDA-glutamate receptors, the smooth muscle cells tone, and the contraction-relaxation cycles of all types of muscle cells, acting as $\mathrm{Ca}$ antagonists (30). The myocardial membrane sodium gradient is maintained by a Mg-dependent Na-K-ADPase (34), and increasing extra/intracellular $\mathrm{Mg}$ concentration inhibit T- and L-type Ca channels (35). Consequently, infusion of $\mathrm{Mg}$ resulted in prolonged atrioventricular node conduction, $\mathrm{PR}$ or QRS durations, and the prolongation of the atrial and ventricular refractory periods (36). In pregnancy, oral $\mathrm{Mg}$ supplementation is used to reduce the risk of preterm birth (37). Another field of employment for $\mathrm{Mg}$ is rheumatology, with regards to the chronic management of patients affected by fibromyalgia (FM), a rheumatic non-inflammatory disease characterized by chronic widespread pain, diffuse hyperalgesia, muscle spasms, fatigue, irritable bowel syndrome, sleep disorders, cognitive and mood disturbances. Etiologically, the strongest evidence points to the alteration of pain modulation in the central nervous system; nonetheless, peripheral abnormalities such as local hypoxia may facilitate peripheral nerve sensitization $(38,39)$. Secondly, deregulation in the sympathetic autonomic and hypothalamic-pituitary-adrenal systems was also described in FM (40). The rationale of use is the relative decrease of $\mathrm{Mg}$ levels in FM patients, namely in muscle cells or erythrocytes (4I-43); moreover, a daily oral Mg supplementation improves FM symptoms (4I, 44). In light of recent knowledge on the central nervous origin of pain associated with fibromyalgia, $\mathrm{Mg}$ supplementation may be considered useful to inhibit the development of neuropathic pain, thanks to its antagonist action on NMDA receptors, which are important in the process of central sensitization (2).

In conclusion, our analysis of Moscati's medical prescription suggests the high scientific value of the doctor, who formulated a diagnosis that shows his attention to a correct definition of a patient's clinical status, with a view to its etiopathogenesis, despite the scarcity of diagnostic instruments of the time. The text of this medical prescription also supports the piety of Moscati (in 1987, the pope Johannes Paulus II canonized G. Moscati, "the physician of the poor", into a catholic church saint), who did not bother to inform the patient about the probable adverse effects of the therapy prescribed, and at the same time gave indications on how to deal with these problems. Last but 
not least, we suggested that Moscati's prescription of $\mathrm{MgO}$ might hide a new rational of use of this traditional remedy against the painful neuropathic syndromes.

\section{Acknowledgments}

We thank Prof. Umberto Muscatello for his crucial suggestions regarding the historic recognition of the molecular mechanisms of $\mathrm{Mg}$ in cell physio-pathology.

\section{REFERENCES}

1. Bujalska-Zadrożny M, Tatarkiewicz J, Kulik K, Filip M, Naruszewicz M. Magnesium enhances opioid-induced analgesia - What we have learnt in the past decades? Eur J Pharm Sci. 2017; 99:113-127.

2. Srebro D, Vučković S, Milovanović A, Košutić J, Vujović KS, Prostran M. Magnesium in pain research: state of the art. Curr Med Chem. 2017; 24:424-434.

3. Durlach J, Bac P, Bara M, Guiet-Bara A. Physiopathology of symptomatic and latent forms of central nervous hyperexcitability due to magnesium deficiency: a current general scheme. Magnes Res. 2000; 13:293-302.

4. Kutlesic MS, Kutlesic RM, Mostic-Ilic T. Magnesium in obstetric anesthesia and intensive care. J Anesth. 2017; 31:127-139.

5. Maasumi K, Tepper SJ, Kriegler JS. Menstrual Migraine and Treatment Options: Review. Headache. 2017; 57:194-208.

6. Holdcraft LC, Assefi N, Buchwald D. Complementary and alternative medicine in fibromyalgia and related syndromes. Best Pract Res Clin Rheumatol. 2003; 17:667-83.

7. Ponti G, D’Onofrio F, Ruini C, Muscatello U, Tomasi A. Giuseppe Moscati: a man, a physician and a scientist. Acta Med Hist Adriat. 2015; 13:171-80.

8. Ponti G, Tomasi A. Giuseppe Moscati (1880-1927): a holistic approach to medicine. J Med Biogr. 2014; 22:80-2.

9. Cascella M. Prof. Giuseppe Moscati (1880-1927). A special issue on his scientific production. Acta Med Hist Adriat. 2016; 14:9-40.

10. Hodgkin AL, Keynes RD. Movements of labelled calcium in squid giant axons. J Physiol. 1957; 138:253-81.

11. Skou JC. The influence of some cations on an adenosine triphosphatase from peripheral nerves. Biochim Biophys Acta. 1957; 23:394-401.

12. Muscatello, U., Andersson Cedergren, E., Azzone, G. F. \& von der Decken, A. The sarcotubular system of frog skeletal muscle. A morphological and biochemical study. J. Biophys. Biochem. Cytol. 1961; 10:201-218. 
13. Muscatello, U., Andersson Cedergren, E. \& Azzone, G. F. The relaxing effect of the sarcotubular system. Biochim. Biophys. Acta. 1961; 51:426-428.

14. Mazzarello P, Calligaro A, Vannini V, Muscatello U. The sarcoplasmic reticulum: its discovery and rediscovery. Nat Rev Mol Cell Biol. 2003; 4:69-74.

15. Weber, A. \& Winicur, J. The role of calcium in the superprecipitation of actomiosin. J. Biol. Chem. 1961; 236:3198-3202.

16. Weber, A., Herz, R. \& Reiss I. On the mechanism of the relaxing effect of fragmented sarcoplasmic reticulum. J. Gen. Physiol. 1963; 46:679-702.

17. von Schroff C. Trattato elementare di materia medica e terapeutica con applicazioni alla farmacopea. Stamperia e Cartiera del Fibreno, Napoli, 1874. p.351-359.

18. Virey JJ. (Italian ed. by Sembenini GB). Trattato compiuto di Farmacia teorica e pratica. Verona, 1834. p.606.

19. Massalongo R. Atti del Reale Istituto veneto di scienze, lettere ed arti. Vol. 76. Venezia, 1916. p.637-644.

20. McNutt WF. Sulphur as a remedy for rheumatism. Cal State J Med 1917; 15:30.

21. Eulenburg A, Guttmann P. (Italian ed. by Manzi B.). La patologia del simpatico compilata con la guida della fisiologia. Milano, 1872. p.118-119.

22. Eulenburg A. Neuralgia gastrica. Baltimore Med J 1870; 1:398-402.

23. Pirera A. Compendio di Patologia e Clinica Medica. Milano, 1925. Vol. II, p. $23-25$.

24. Shlereth FA. Dispensatorium fuldense tripartitum tam patriae usibus quam saeculi moderni genio accomodatum. Francofurti ad Moenum apud Henricum Ludovicum Broenner, 1791. p.121-122.

25. Duncan A Jn. The Edinburgh new dispensatory. Seventh edition, Edinburgh: printed for Bell \& Bradfute, 1813. p.383.

26. Cassola F. Trattato di chimica elementare estesamente applicata alla medicina, alla farmacia, all'agricoltura, alla mineralogia, ed alle arti. Stamperia e Cartiera del Fibreno, Napoli, 1837. p.186-188.

27. Tommasi S, Cantani A, Cavallo P, De Sanctis TL. Il Morgagni. Vol. 12. Tipografia Italiana, Napoli, 1870. p.290.

28. Guslandi M. Relapsing ulcers and mucosal protecting agents. Lancet 1981; $1: 387$.

29. Jappelli A. Influenza del magnesio sulla contrazione veratrinica del muscolo striato. Boll Soc Biol Sper 1927; 2:30.

30. Winer Ashkenaz E. Magnesium narcosis in muscle. J Cell Compar Physiol 1938; 11:163-174.

31. Hubbard JI. The effect of calcium and magnesium on the spontaneous release of transmitter mammalian motor nerve endings. J Physiol 1961; 159:507-17.

32. White RE, Hartzell HC. Effects of intracellular free magnesium on calcium current in isolated cardiac myocytes. Science 1988; 239:778-80. 
33. Altura BM, Altura BT. Tension headaches and muscle tension: is there a role for magnesium? Med Hypot 2001; 57:705-13.

34. Mubagwa K, Gwanyanya A, Zakharov S, Macianskiene R. REgulation of cation channels in cardiac and smooth muscle cells by intracellular magnesium. Arch Biochem Biophys 2007; 458:73-89.

35. Wu J, Lipsius SL. Effects of extracellular Mg2+ on T- and L-type Ca2+ currents in single atrial myocytes. Am J Physiol Heart Circ Physiol 1990; 259:H1842-50.

36. Baker WL. Treating arrhythmias with adjunctive magnesium: indentifying future research directions. Eur Heart J 2017; 3:108-117.

37. Makrides M, Crowther CA. Magnesium supplementation in pregnancy (Review). Cochrane Database Syst Rev 2001; 4:CD000937.

38. Sluka KA, Clauw DJ. Neurobiology of fibromyalgia and chronic widespread pain. Neuroscience. 2016; 338:114-129.

39. Sawaddiruk P, Paiboonworachat S, Chattipakorn N, Chattipakorn SC. Alterations of brain activity in fibromyalgia patients. J Clin Neurosci. 2017; 38:13-22.

40. Romano GF, Tomassi S, Russell A, Mondelli V, Pariante CM. Fibromyalgia and chronic fatigue: the underlying biology and related theoretical issues. Adv Psychosom Med. 2015; 34:61-77.

41. Abraham GE, Glechas JD. Management of fibromyalgia: a rationale use of magnesium and malic acid. J Nutr Med 1992; 3:49-59.

42. Eisinger J, Plantamura A, Marie PA, Ayavou T. Selenium and magnesium status in fibromyalgia. Magnes Res 1994; 7:285.

43. Romano TJ, Stiller JW. Magnesium deficiency in fibromyalgia syndrome. J Nutr Med 1994; 4:165-167.

44. Bagis S, Karabiber M, As I, Tamer L, Erdogan C, Atalay A. Is magnesium citrate treatment effective on pain, clinical parameters and functional status in patients with fibromyalgia? Rheumatol Int 2013; 33:167-72.

\section{SAŽETAK}

Prikazali smo i razmotrili zanimljivu medicinsku terapiju doktora Giuseppea Moscatija (1880. - I927.) koji je propisao magnezijev oksid (magnesia usta) pacijentu s dijagnozom "neuralgije celijačnog pleksusa reumatoidnog podrijetla". Osim tradicionalne upotrebe magnezija kao antacidnog lijeka u to doba, pretpostavili smo da je Moscati propisao magnezij kako bi liječio samu neuralgiju. Sobzirom na znanstvenu pozadinu Moscatija u školi Filippa Bottazzija (I867. - I941.), oca talijanske biokemije, sugerirali smo da je liječnik pokušao primijeniti preliminarne koncepte dobivene iz elektrofizioloških istraživanja na magneziju u svoju kliničku praksu. Tek nakon nekoliko desetljeća magnezij je prepoznat kao temeljni ion $u$ energetskom metabolizmu koji pridonosi održavanju ionske intracelularne homeostaze, uključujući i neurona.

Ključne riječi: Giuseppe Moscati, Filippo Bottazzi, magnezijev oksid, magnesia usta, neuralgija, cilijanični pleksus 